\title{
SEEPS AND SPRINGS AT A PLATTEVILLE "OBSERVATORY" ON THE RIVER BLUFFS
}

\author{
BJ Bonin \\ Independent Contract Geologist, 284 Macalester Street, St.Paul, MN, 55105 USA bjbonin1@yahoo.com \\ Greg Brick \\ Department of Earth Sciences, University of Minnesota, Minneapolis, MN, 55455 USA bric0004@umn.edu \\ Julia Steenberg \\ Minnesota Geological Survey, 2609 Territorial Road, St.Paul, MN, 55114 USA and001006@umn.edu
}

\begin{abstract}
Residential building construction along the Mississippi River bluffs in the 1970s created a unique enclosed outcrop of the Late Ordovician Platteville Formation at Lilydale, Minnesota. This outcrop was examined in early 2013 after a newly-formed spring flooded an elevator shaft the previous year, drawing attention to the foundation conditions.
\end{abstract}

The Lexington Riverside property is a six story condominium complex constructed within the top of the bluff. A two-level underground parking garage was built into the bluff. Bedrock was mechanically excavated to accommodate the construction of the building, creating an unweathered rock surface. The space between the structure and the excavated rock face, running for 150 meters, was roofed over, and is used as a utility space. At least three dominantly carbonate members of the Platteville Formation are visible: Mifflin, Hidden Falls, and Magnolia, in ascending order. The foundation of the structure was constructed on the lowermost Platteville limestone and Glenwood shale and is tile-drained to the nearby river gorge.

Most of the seeps and springs on the property, both inside and on the grounds, belong to the three Platteville spring-lines identified for the Twin Cities Metropolitan (TCM) area by Brick (1997). Groundwater emanates from both vertical joints and horizontal bedding plane partings within the Platteville Limestone and at the Plat-
teville-Glenwood Shale contact. Overall, the hydrostratigraphic attributes of this site are consistent with how the Platteville has been recently characterized in the TCM area in a fractured bluff edge setting (Anderson et al., 2011).

The enclosed outcrop features many seep- and springrelated mineral deposits. Most notable were the ironstained flowstone and microgours near the seeps and springs along fractures in the limestone, and calcite rafts on the surfaces of the pools. At some damp locations a fungal ecosystem has developed. Gypsum beards have grown in dry portions of the cavern.

This man-made cavern, and others nearby, present unique opportunities to research groundwater flow in fractured bedrock settings. Studying the spring locations relative to joints and bedding, changes in spring flow rate over time, and mineral deposition rates, are possible in this accessible location without the complication of surface water inputs or instrumental interference from the general public.

\section{References}

Anderson, JR, Runkel, AC, Tipping, RG, Barr, KDL, and Alexander, EC, Jr. 2011. Hydrostratigraphy of a fractured, urban aquitard. Geological Society of America Field Guides, v. 24: 457-475.

Brick, G. 1997. Along the Great Wall: Mapping the Springs of the Twin Cities. Minnesota Ground Water Association Newsletter 16(1): 1-7. 
